
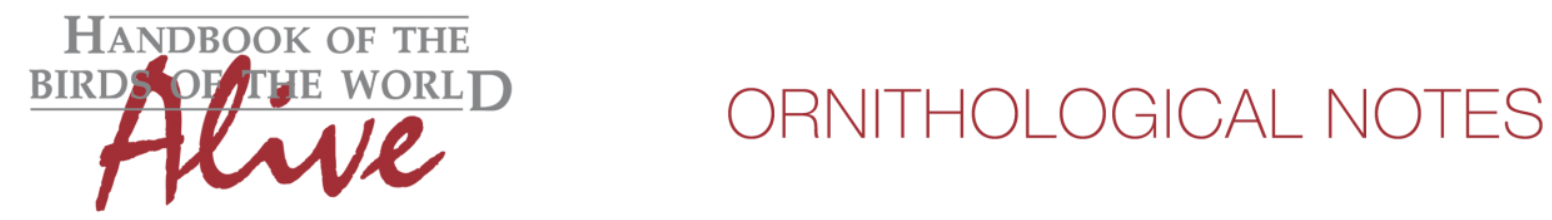

\title{
Notes on the vocalizations of Mouse-colored Tyrannulet (Phaeomyias murina)
}

\author{
Peter Boesman
}

In the following we briefly analyze and compare voice of the different races of Mousecolored Tyrannulet (Phaeomyias murina). We also try to quantify the extent of any vocal differences using the criteria proposed by Tobias et al. (2010), as a support for taxonomic review. We have made use of sound recordings available on-line from Xeno Canto (XC).

There are few recordings available of dawn song of all taxa, for which it is better to focus on day-time song.

Day-time song of all except Tumbesian races is a usually gravelly nervous series of notes which suddenly increases in amplitude and pitch: "je-je-je-je-jE-JE-JEE-Jew", with minor variations (last note lower in pitch and amplitude).

Day-time song of Tumbes birds is quite different: a short phrase of about 5 notes, typically a few fairly squeaky and a few rather gravelly (Fig. 1). (Also a variety of calls, including a peculiar fast rising rattle, different from any vocalization of the other races).

Measurements of day-time song:

$\underline{\text { Tumbes birds }(n=4)}$

$\begin{array}{ll}\begin{array}{ll}\text { Amplitude ratio } \\ \text { (second part/first part) }\end{array} & 0.7-1.0 \text { approx. } \\ \text { total length } & 0.485-1.06 \mathrm{~s} \\ \text { \# of notes } & 4-7 \\ \text { lowest max. freq. } & 2000-3200 \mathrm{~Hz} \\ \text { highest max. freq. } & 3800-5000 \mathrm{~Hz} \\ \text { typical note length } & 0.04-1.0 \mathrm{~s} \\ \text { note shape } & \text { irregular, mix of long and short notes }\end{array}$

Other races $(n=10)$

$\begin{array}{ll}\begin{array}{l}\text { Amplitude ratio } \\ \text { (second part/first part) }\end{array} & >4 \\ \text { total length } & 1.00-1.53 \mathrm{~s} \\ \text { \# of notes } & 10-14 \\ \text { lowest max. freq. } & 2300-3600 \mathrm{~Hz} \\ \text { highest max. freq. } & 4150-5600 \mathrm{~Hz} \\ \text { typical note length } & 0.06-0.085 \mathrm{~s} \\ \text { note shape } & \text { fairly rounded and overslurred, sometimes more burry, regular }\end{array}$

Tumbesian birds thus differ vocally by a rather stable amplitude over the duration of a song phrase (score 3), a shorter duration of the song phrase (score 1-2), fewer notes in the song phrase (score 3 ) and more irregular note shapes (score 1). Several calls also very different. When applying Tobias criteria, this would lead to a total vocal score of 6. 

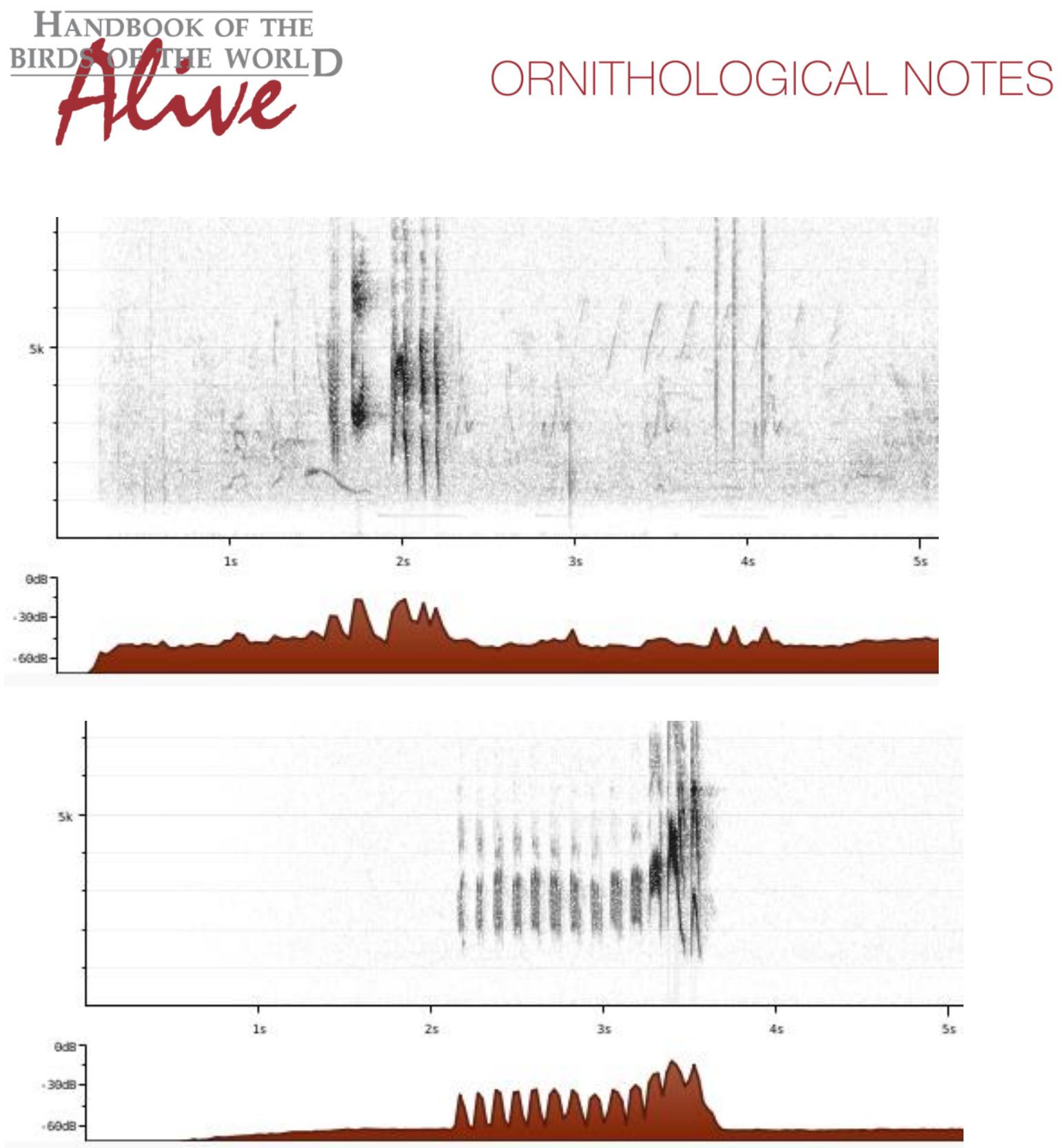

Figure 1: sonogram and amplitude diagram of typical day-time song of Tumbesian races (top) and other races (bottom)

This note was finalized on 25th June 2015, using sound recordings available on-line at that moment. We would like to thank in particular the many sound recordists who placed their recordings for this species on XC.

\section{References}

Tobias, J.A., Seddon, N., Spottiswoode, C.N., Pilgrim, J.D., Fishpool, L.D.C. \& Collar, N.J. (2010). Quantitative criteria for species delimitation. Ibis 152(4): 724-746.

\section{Recommended citation}

Boesman, P. (2016). Notes on the vocalizations of Mouse-colored Tyrannulet (Phaeomyias murina). HBW Alive Ornithological Note 138. In: Handbook of the Birds of the World Alive. Lynx Edicions, Barcelona. (retrieved from http://www.hbw.com/node/932062 on 10 August 2016). 